\title{
ADMINISTRATIVE PROBLEMS IN THE COLLECTION OF CONTRIBUTIONS
}

\author{
Arthur E. Wegner*
}

With the passage of unemployment compensation laws by states and the passage of the enabling Federal Social Security Act, the administration by the states of these laws becomes of general interest. The work of administration falls naturally into two major divisions: the collection of the funds out of which unemployment benefits are payable, and the payment of the unemployment benefits. This division is accentuated also by the element of time-benefit payments follow by two years the beginning of the collection of the benefit fund contributions. This deferment of benefit payments is definitely provided under the Federal Social Security Act, ${ }^{1}$ a provision which the state laws must follow in order that credit against the federal tax may be accorded contributions to state compensation funds.

Since the first benefits become generally payable in Wisconsin (the first state to enact unemployment compensation) after July, I936, and in no other state until r938, this discussion must be limited to the one division of unemployment compensation administration-the collection of contributions. This presentation is based primarily on the experience in the administration of Wisconsin's law during the eighteen months since it became effective.

The collection of funds for benefit payments presumes a legislative enactment defining the individuals, firms, or entities on whom is imposed a contribution at a given rate on a given defined base. The problems of the collection then separate into three major groups:

I. Coverage of the law (that is, on whom does the liability of contributions fall) and the attending administrative problems of interpreting legislative intent with respect to the persons subject to the law and of ferreting those persons out of all persons potentially subject to it.

2. Defining legislative intent as to the base on which contributions are payable.

3. The actual collection of the contribution with its attending problems of records, forms, and reports, and the all important problem of delinquency.

- A.B., 1927, University of Wisconsin. Director of Contributions, Unemployment Compensation Department, Industrial Commission of Wisconsin. Member, American Society of Certified Public Accountants.

${ }^{1}$ Public, No. 27r, 74th Cong., Ist Sess. (1935) tit. IX, \$903 (a) (2). 


\section{Coverage of the Law (Who are Liable for Contributions)}

Every unemployment compensation act passed by any state legislature imposes contributions, and the Federal Social Security Act, taxes, on the "employer." Employer" is usually defined as any person, partnership, association, or corporation, or legal representative, who has or has had in his employ a given number of individuals for a minimum period in employments not specifically excepted by the respective acts. To reach the employer who is subject to the act is then the first problem of those who administer a state unemployment compensation act.

Every administrative office must assume that a vast number of employers are currently posted on legislation through their own attentiveness to current progress, and through advice of legal counsel and accountants, and these employers, who are the majority of the subject group, voluntarily contact the administrative office. The remaining employers-still a goodly number-must be contacted by the department. These employers can be reached through various departmental lists. There are, for example, in states where workmen's compensation laws are effective, fairly comprehensive lists of firms who have had accident compensation; there are the lists of the Insurance Department, the Banking Commission, the various licensing divisions of the state, such as warehouse, truck operation, restaurant, and the like; there are those lists of firms requiring annual health inspections, and those lists of firms requiring annual registration to keep corporate organization alive. In states where a state income tax is imposed one cannot overlook income tax returns. Aside from lists of employers obtained from other state departments, it is worth noting that employers are generally sufficiently anxious to comply with legislative requirements to permit the use of rosters of trade associations of which they are members.

But the problem of ferreting out employers, though it is a major administrative problem, can be thoroughly handled by intensive and continuous search.

The problem, however, with respect to coverage under an unemployment compensation act reaches its more interesting aspects in those many cases where interpretation of legislative intent is required. The interpretations in these instances must necessarily follow precedents in court cases as well as rulings of other administrative departments. Among the most important of these is the problem of the employment relationship (the contract of hire) in determining whether an individual must be counted to make up the minimum number of employees required to declare an employer subject to the act. Concretely, the following questions with varying degrees of relationship to employers are continually repeated.

Is a salesman, who works on a commission only, and who also handles other lines, an employee of a given employer or of more employers?

Are employees of a subcontractor (who is otherwise not subject to the act) employees of the original employer where the work by such subcontractor is only incidental to the original employer's business? 
Are professional men, who by law can practice only as individuals, employees of those with whom they are associated?

Are soliciting agents of insurance companies employees of the companies they represent? Are they still employees if they also have other means of livelihood?

Are haulers of farm produce employees of the farmer, though actually paid by the company to whom they deliver the produce?

Many of these questions are, of course, answered by the laws themselves, and, where definitely legislated in or out, the problem becomes more easily answered.

There is also to be considered in the matter of coverage of an unemployment compensation act the excepted employments-those employments which the legislature did not intend to cover under the act. Some of the more common exceptions found in many of the state laws are farm and agricultural labor, casual labor, domestic service, and employment by municipalities and by exclusively charitable, religious, educational, or scientific funds or organizations. All of these exceptions need to be given rules and special handling.

After employer lists have been prepared and some of the questions with respect to employers' status answered, the administrative office must circularize the employers potentially subject and must require from employers certain reports which are complete and detailed enough to permit them to determine their own status.

This now becomes the problem of the individual state department and is more or less of a problem depending upon the respective state's law. For example, a state where every employer is subject to the act regardless of the number of persons employed by him, where there are but a few or no exceptions of employment, would have much less of a problem than a state where a minimum of eight persons must be employed to be subject and which has a number of excepted employments.

Such reports must, of course, show something of the history of the employer, something of his type of organization, and the number of persons employed by him in various employments, detailing particularly the excepted employments. These reports must also show the number of persons on the employer's payroll by weeks or comparable payroll periods, or on given days within weeks if the law makes the determination of status on such smaller period.

It is worth noting that the use of the calendar week instead of the day both in determination of employer status and computation of benefits relieves the administration of much of a complicated problem and makes a law more easily understood by both employer and employee.

\section{The Base on Which Contributions are Payable}

In all states which have enacted unemployment compensation laws the contributions imposed by the respective laws are computed on the employer's payroll-wages (remuneration) earned by the employee in personal service for the employer.

This means precisely that every administrative office must deal with the definition of payroll and its related problems. The first problem to solve is the inclusiveness 
of the payroll, i.e., payments in kind, such as room and board, when that forms a part of payment for service; gratuities, such as tips, received by employees and not paid by the employer; the items which the contract of hire alone can best define, such as continued pay during vacation; pensions not paid out of accumulated benefit reserves but as items of payroll; and sick benefits during sick leave not paid out of accumulated benefit reserves. There are the further items often included in the employer's payroll, such as expense allowances, often actual reimbursement for employee's expense outlay, which are probably not payroll for this purpose. And there is always the problem of the basis of accounting (cash or accrual) used by the employer, which becomes more important in dealing with undetermined items, applicable to definite calendar or fiscal periods, such as bonuses and profit shares in payment for services.

Since the base on which contributions are payable is the important factor in the determination of the individual employer's contribution, it cannot be lightly turned away. The administrative office must clearly and definitely rule on items of payroll and wages, and such rulings again must follow customary, good accounting and law.

\section{The Collection of the Contributions}

After the initial steps of determining who is subject to the unemployment compensation act, and after concluding the questions raised with respect to status and payrolls, the whole administration resolves itself into the collection of the contributions imposed. The collection involves all of the questions of reports, records, accounting, benefits, information required for the determination of benefit payments, employment statistics, and the question of centralized information recording. The collection revolves further around the major differences in state laws-the employer reserve as typified in Wisconsin and the pooled fund as found in New York and the District of Columbia, and the further variation of the pooled fund, merit-rating.

In the determination of the reports to be required of employers it is always advisable to design a report which the employer can readily fill out. The report should be inclusive enough to cover all information that may be needed in the central office, even though it may not be immediately tabulated; and the report should nevertheless be simple enough to require no more information than will at some time or other be needed. The employer's contribution report should be required frequently to coincide with accounting periods and to afford the administrative office current information with respect to the employer's delinquency. Too long a period between reports is apt to permit the amount of the payments to become burdensome to the employer and increase delinquency.

Monthly reports have been required in Wisconsin. Some states definitely intend to require reports at the close of each payroll period, and other states, it has been said, are contemplating semi-annual reports. Experience in Wisconsin has been favorable to the continuance of monthly reports-employers readily accustom themselves to periodic reporting. More frequent reports, it may be found, add to the em- 
ployer's clerical cost, while less frequent reports may disturb that regularity and cause greater delinquencies.

To aid in the regularity of reporting, Wisconsin mails out to employers at the close of each month printed forms on which payroll data is to be submitted. These forms bear the name, address and identification number of the employer, and he need supply merely the payroll information. Due dates for all reports have been staggered throughout the month to avoid peak loads.

For administrative feasibility, admitting that the report forms must be designed to meet statutory requirements, it is nevertheless desirable that the contribution base be, as nearly as possible, the employer's total payroll. Aside from the fact that total payroll would yield contributions more adequate to meet benefit payments, it must be recognized that every exclusion increases the administrative costs and problems.

With respect to both employer reserves and merit-rating pooled fund systems, the administrative office has the problem of recording payrolls and contributions by individual employers. This becomes necessary when it is realized that a reserve system provides that benefits shall be payable to the unemployed individuals of an employer only from the funds contributed by the given employer, and becomes obviously necessary for merit-rating pooled fund systems when it is realized that merit rating involves the determination of the benefit payments in relation to an employer's contributions.

One of the problems every administrative office must determine, when it begins to administer an unemployment compensation act, is the necessity or desirability of centrally recording the earnings of individual employees, as is now being done in New York State and the District of Columbia, instead of deferring the compilation of data with respect to earnings of an unemployed individual until a claim for benefits arises, as Wisconsin proposes to do. The conclusion depends a great deal upon the determination of the benefit payments. The longer the period on which benefit payments are determined, the more necessary it becomes to have the individual employee's earnings recorded in a central office. The shifting of the employee to other employers and the obvious administrative detail in securing employment data from employers no longer in business tend to make such centralization desirable. On the other hand, to require voluminous employer reports will tend to discourage the good will of the employer, since it greatly increases his cost, while only a small portion of the information will actually be needed. The majority of the employees involved are not apt to become unemployed and file claims for benefits. The recording, too, of all of this information by the central office places upon it an undue administrative volume.

After the administrative office has determined the type of report the employer should be required to file and has determined to what extent employers should detail the payrolls reported, the problem then is to plan the routing of the reports and the mechanics of handling them. State statutes generally require that receipts be issued 
for any moneys collected by a department and that such receipts be issued promptly and often, in duplicate or triplicate, and that the moneys collected be promptly deposited. To this extent reports should be checked as promptly as possible, and the contribution remittances deposited. After receipt of the reports and the prompt issuing of receipts and depositing of money, the reports can be more leisurely routed to be recorded, rechecked for accuracy, and used for statistical purposes.

The collection of contributions involves also an examination of employers' records, first of all, to help employers understand some of the problems they face in their establishments, and second, to satisfy the administering department that payrolls are correctly reported. For this purpose traveling representatives, who are familiar with accounting and payroll records, can best be used.

And not least among the problems of collecting contributions is the employer's own record. Every administrative office will be called upon to advise employers what records they may be required to keep to best reflect and disclose the information the department may desire. The department, it would seem, can best help the employer in this respect by issuing notice to him of the information it is going to ask and in what form and under what circumstances it will be required. Generally, the less interference a department must cause an employer in the change of his record, the more readily will the information be forthcoming.

Finally, after collections are being apparently well administered and no particular difficulty appears, the collecting officer must contend with the ever present problem of delinquency. Truly, every state law has penalty provisions and means of enforcing them, and such enforcing measures should be used in case of obstinate, recalcitrant employers. In addition to the fine and imprisonment penalties for wilful refusal to comply with any of the law's provisions, Wisconsin has an interest penalty ( $1 \%$ a month) on delinquencies, which has had a salutary effect on collections.

But the real problem facing the collector is how far should the penalty provisions be enforced on delinquent employers, whose financial position is such that they cannot actually make contribution payments, but who are striving to keep employed the employees now on their payrolls. In other words, to what extent should an administrative department of unemployment compensation carry its administration to the immediate benefit or detriment of employees now employed?

Above all, it cannot be emphasized too strongly that the successful administration of an unemployment compensation act presupposes a well-trained and efficient personnel. Wisconsin in this respect is fortunate to have a well-administered civil service law, and selections have been made from the examination lists prepared.

Briefly, in conclusion-unemployment compensation legislation is the result of need visualized by both the employer and the employee, and the administration of the law can be made relatively simple if the administrative department does not overlook that the employer on the one side and the employee on the other are anxious to aid in the solving of the problems. 